\title{
INFLUENCE OF STRUCTURE OF MANUFACTURING SYSTEM AND AMOUNT OF INVESTMENT ON PRODUCTION COSTS
}

\author{
Edin Cerjaković, Alan Topčić, Džemo Tufekčić, Ivica Veža
}

Preliminary notes

Today's business of manufacturing systems is entirely dictated by the dynamics of the market and every day there is a need for adjustment of the structure and parameters of associated manufacturing systems. Those adjustments should ensure the operation of manufacturing systems in more favourable manufacturing and economic conditions, and often this process is directly linked with the starting of investment process. On the other hand, every day practice proves that evaluation of investment program during selection of structure of manufacturing system with the aim to accomplish production plans and reduction of production costs is often based on insufficient sets of information. Lack of information may result in inappropriate insight into overall techno-economic effects that can be achieved by investment program. Within this paper are presented researches which resulted in development of a new systematic approach in the analysis of potential structures and parameters of manufacturing systems with the aim to plan, project or reengineer manufacturing systems on the basis of minimal production costs.

Keywords: equipment structure; investments; material flow; manufacturing system; production costs; simulation

Utjecaj strukture proizvodnog sustava i opsega investicije na troškove proizvodnje

Prethodno priopćenje

Poslovanje današnjih proizvodnih sustava u potpunosti je diktirano dinamikom tržišta te se svakodnevno javlja potreba za prilagodbom strukture i parametara proizvodnog sustava kako bi se poslovalo u što povoljnijim tehnološkim i ekonomskim uvjetima, a nerijetko je ovaj process vezan i s ulaskom u investicijski postupak. S druge strane, praksa dokazuje da je ocjena investicijskog programa pri odabiru strukture proizvodnog sustava u cilju ostvarenja planirane proizvodnje i smanjenja troškova proizvodnje često zasnovana na nedovoljnom skupu informacija, tako da se ne dobiva relevantna slika o tehno-ekonomskim efektima koji će biti posljedica investicijskog programa. U okviru članka prikazani su rezultati istraživanja koji su doveli do razvoja metodičkog pristupa analize mogućih struktura i parametara proizvodnog sustava u cilju planiranja, projektiranja ili reinženjeringa proizvodnog sustava na bazi minimalizacije troškova proizvodnje.

Ključne riječi: investicija; simulacija; struktura opreme; proizvodni sustav; tok materijala; troškovi proizvodnje

\section{Introduction}

Today's business of manufacturing systems is entirely dictated by the dynamics of the market i.e. by the relationships between supply and demand. Failure to meet or even inadequate response to a set of market requirements may result in the loss of business engagement. Sesterhenn [1] states that the optimal structure of manufacturing systems is constantly exposed to newly created stochastic changes and over the time is transformed into suboptimal structures which again need to be the subject of processes of optimization. In order to prevent the previously mentioned scenario it is necessary to invest in improvement of characteristics of manufacturing system with the aim to increase the production capacity, reduce production costs while simultaneously maintaining or improving the existing qualitative characteristics of products. On the other hand, "freezing" of capital through investments in crisis time, but in normal business conditions too, can result in insolvency of manufacturing systems which can be disastrous for their existence. Based on the above mentioned it is important to find an adequate structure as well as to see when and to what extent it is justified to invest in order to improve the production capacity and performance of manufacturing system with the aim to gain optimal working parameters in accordance with established criteria. Koren, $\mathrm{Hu}$, and Weber [2] have demonstrated that the system configuration (the arrangement of the machines and the interconnection among them) has a significant impact on six key performance criteria: 1) investment cost of machines and tools, 2) quality, 3) throughput, 4) capacity scalability, 5) number of product types, and 6) system conversion time. Cochran et al [3] have presented a MSDD methodology (Manufacturing System Design Decomposition) which is based on the decomposition of working positions and operations in order to meet certain functional requirements (FR) to design solutions by applying axiomatic design. First functional requirement (FR1) in this methodology is to maximize the return of investments (ROI), represented by equation (1), which points out the importance of taking into account the payback time in the process of design of manufacturing system.

$R O I=\frac{\text { Sales }- \text { Cost }}{\text { Investment }}$

On the other hand, manufacturing systems are complex objects with many integrating factors and internal relations, where it is difficult to understand all the phenomena and changes of performance completely. Therefore the design of manufacturing system in general, and thus the configuration of the potential structure of a manufacturing system into one functional unit is a specific challenge, especially taking into account that there are a multitude of requirements connected with characteristics of such a system. Westkamper [4] in his research states that in the period of $1995 \div 2005$ the need for planning within the scope of manufacturing systems is tripled, while simultaneously the time for the design is reduced by $75 \%$. It can be assumed that the trend is continued even after the year 2005, which additionally complicates the process of design of a manufacturing 
system. Today's research in the field of design of manufacturing systems structure is mostly orientated towards reconfigurable manufacturing systems (RMS), which have substantial demands toward fast changes of their own structure, [5]. RMS has a finite number of machines and a variable number of different types of products on the basis of which the structure of a manufacturing system is generated. During the construction of new or reconfiguration of existing manufacturing systems, the main problem is how to choose the right ones, from numerous different machines that come into consideration for the creation of potential structures and production of the final number of different types and quantity of products. Considering the variation of manufacturing system structures in dependence on the number of available machines, the amount of potentially available structures significantly increases, while there is a possibility of reducing this number for structure of reconfigurable manufacturing systems, Tab. 1 [6].

Table 1 Total amount of system configurations for different numbers of machines

\begin{tabular}{|c|c|c|}
\hline $\begin{array}{c}\text { Number of } \\
\text { machines }\end{array}$ & $\begin{array}{c}\text { Number of possible } \\
\text { configurations }\end{array}$ & $\begin{array}{c}\text { Number of RMS } \\
\text { configurations }\end{array}$ \\
\hline 2 & 2 & 2 \\
\hline 4 & 15 & 8 \\
\hline 6 & 170 & 32 \\
\hline 8 & 2325 & 128 \\
\hline 10 & 35341 & 512 \\
\hline
\end{tabular}

Korean and Shpitalni in their work [5] analyze the structure of manufacturing system in terms of determination of the number of possible structures of reconfigurable manufacturing systems, and present the effects of variations in structure, without cost analysis of all possible structures. On the other hand Azab and ElMaraghy [7] present a mathematical model for reconfigurability of processing planning through observing variations of individual operations with appropriate tools on the basis of processing costs. This approach offers a quick, feasible and optimal solution albeit not the exact global optimum.

Considering that characteristics and structure of manufacturing system are determined by flows of material, energy and information where stochastic material flows have the most important role, there is a need to analyse production costs of manufacturing systems based on their corresponding flows. Cerjaković et al [8] suggest that implementation of simulation study represents the only acceptable solution because of the fact that conventional methods for balancing of material flow within manufacturing systems do not have the possibility to take into account the dynamic nature of processes which take place in modern manufacturing systems. At the same time implementation of the simulation studies for an analysis of manufacturing systems is a complex and time-consuming process, whose result largely depends on the quality of input data, the level of model details, and competencies of workers who create and perform simulation studies.

Relevant investment analysis which will be applied for determination of required structure of manufacturing systems needs to include all relevant parameters of direct costs (costs of labour, machinery, tools, emulsions, energy, transportation, quality control, storage, maintenance, montage, etc.) and costs of unused resources i.e. technical indirect production costs (appearance of bottlenecks and malfunctions, lack of energy, work resources, production materials, etc.) projected on time of investment repayment.

Considering to previous observations, in this paper will be indicated the importance of integration between analysis of stochastic processes within manufacturing system and its projection on indicators of production costs, as well as analysis of investment process in order to give an answer to which kind of structure and with which parameters to accomplish planning, projecting or reengineering of manufacturing systems on the basis of minimal production costs. The focus of presented research is directed to achieving a comprehensive analysis of existing capabilities from a set of applicable solutions.

\section{Problem description}

The primary problem of research presented in this paper is based on insufficiently explored area of mutual interaction of manufacturing and economic impacts during evaluation of potential investment for expanding of capacity, the design of new or re-engineering of existing structure and working characteristics of manufacturing systems for series production in order to reduce the total production cost.

Additional issues in this process create the need for maintaining the necessary level of competitiveness of the system, i.e. manufacturing systems must constantly apply introduction of new and/or innovation of existing technologies and methods for the processing, transportation/handling, control and assembling of products. This suggests that during the lifetime of manufacturing systems, as a result of the introduction of new products, processes, modification in the processing operations or especially in modifications of associated internal material flows, daily changes of boundary conditions are occurring. Analysis of the performance of such internal material flows is a complex task, because the processes themselves have dynamic and stochastic character i.e. a multitude of processes in accordance to some of the random variables are taking place. Therefore, the solution of choice of adequate structures of working elements of material flow within the observed manufacturing system and its operating parameters should be based on a thorough knowledge of the interaction that takes place between individual units during the manufacturing process within the manufacturing system. Namely, for every manufacturing system it is especially important that its segments have a greater degree of efficiency in order to reduce overhead costs as much as possible, i.e. achieve the maximum possible profit.

Current approaches to determination of the most favourable structure of manufacturing systems are based on considering and focusing on the choice of structure of manufacturing systems according to partial analyses that do not take into account all the possibilities and all disturbance values, thereby consciously defining suboptimal structures and parameters of manufacturing systems, i.e. suboptimal investment program. Secondary issue of research is a wide range of stochastic factors 
which have significant role during realisation of manufacturing process and its interactions with structure of manufacturing systems which results in ability to define mathematical functions for determination of observed dependencies. In this case it is necessary to separately examine every possible situation of the considered problem, which also makes difficult the process of structuring, analysis and evaluation of the investment process. Therefore the problem of presented research can be divided in two groups:

1. Problem of integration of structural and parametric optimization,

2. Problem of choice of relevant parameters for technoeconomical comparison of individual situations.

On the basis of the previously described problem of research, the objective of this paper is to present an innovative approach to solving the problem of choice of investment program, which is defined on the basis of structures of manufacturing system in order to achieve production with the lowest production costs.

\subsection{The problem of integration of structural and parametric optimization}

Since it is well known that most of processes of material flow within the manufacturing system have a stochastic character $[8 \div 11]$, there is a question: "Is there a sufficient volume of information to start the investment process based on the optimization of the structure and parameters of manufacturing systems, and to thereby meet the demand for production with minimal costs?"

One of approaches for analysis of stochastic material flow involves the application of simulation study based on simulation of discrete events. Lack of this methodology in analysis of potential structure of manufacturing systems is absence of organized approach to designing of simulation experiments, but analysis is based on modality "What $\div$ If?". The disadvantage of this approach is the fact that it does not observe the impact of the economic effects of possible combinations of production equipment (machine, tools, devices, etc.) with corresponding mutual influences on the choice of final structure of manufacturing system. Usage of statistical plans of experiments for this purpose is inadequate because there are no possibilities for validation of structure and state of observed system, for example kind of production equipment, grouping of production equipment aiming to arrange servicing of machines by workers and so on, which cannot be observed as continuous parametric values. Therefore, it is necessary to find opportunity that these values can be treated as input variables in the process of planned experiment.

Proposal of authors in this paper is to treat those input values as discrete inhomogeneous states, i.e. the values of parameters will be stipulated with some of the measurable characteristics of observed non parametric variables (e.g. production capacity of production equipment with the aim to involve the structure of the plan of the experiment). Considering that this principle is satisfactory if the production equipment can respond to the required characteristics of production at a particular workplace (corresponding machining operation/s) it is necessary to define a general rule. In particular, for the case that the production equipment needs to be a combination of several elements, the developed methodology is presented by the example in Tab. 2 .

Table 2 An example of variation, selection and coding of the structure of machining operations within the analysis of manufacturing systems

\begin{tabular}{|c|c|c|c|c|c|c|c|c|c|c|c|}
\hline \multicolumn{12}{|c|}{ Limits } \\
\hline \multicolumn{3}{|c|}{$Q_{\mathrm{op}-\min }=950 \mathrm{pcs} / \mathrm{shift}$} & \multicolumn{6}{|c|}{$\vartheta=1,25$} & \multicolumn{3}{|c|}{$Q_{\mathrm{op}-\max }=\vartheta \cdot Q_{\mathrm{op}-\min }=1188 \mathrm{pcs} / \mathrm{shift}$} \\
\hline \multicolumn{12}{|c|}{ Balance of capacity } \\
\hline$M_{i}$ & $F$ & $K+I$ & $M$ & $7 \cdot F$ & \multicolumn{2}{|c|}{$8 \cdot F$} & \multicolumn{2}{|c|}{$9 \cdot F$} & $10 \cdot F$ & $F+K+I$ & $2 \cdot F+K+I$ \\
\hline$Q_{u k}$ & 130 & 817 & 140 & 910 & \multicolumn{2}{|c|}{1040} & \multicolumn{2}{|c|}{1170} & 1300 & 947 & 1077 \\
\hline$M_{i}$ & $K+I+M$ & $K+I+2 \cdot M$ & $6 \cdot M$ & $7 \cdot M$ & \multicolumn{2}{|c|}{$8 \cdot M$} & \multicolumn{2}{|c|}{$4 \cdot F+4 \cdot M$} & \multirow{2}{*}{\multicolumn{3}{|c|}{$Q_{\mathrm{op}}=950 \div 1188 \mathrm{pcs} / \mathrm{shift}$}} \\
\hline$Q_{u k}$ & 957 & 1097 & 840 & 980 & \multicolumn{2}{|c|}{1120} & \multicolumn{2}{|c|}{1080} & & & \\
\hline \multicolumn{12}{|c|}{ Balance of labour } \\
\hline$M_{i}$ & $F$ & $K+J$ & $M$ & $8 \cdot F($ & & & $\mathrm{K}+\mathrm{I}$ & & $+\mathrm{I}+\mathrm{M}(2 \cdot \mathrm{M})$ & $7 \cdot M(8 \cdot M)$ & $4 \cdot \mathrm{F}+4 \cdot \mathrm{M}$ \\
\hline$Q_{u k}$ & 130 & 817 & 140 & 1040( & & & & & 957 (1097) & $980(1120)$ & 1080 \\
\hline$k_{u k}$ & 0,3 & 2 & 0,3 & $2,4($ & & & & & $2,6(2,9)$ & $2,1(2,4)$ & 2,4 \\
\hline$k_{s t}$ & \multirow{2}{*}{\multicolumn{3}{|c|}{$k_{\max }=3$ workers }} & \multicolumn{2}{|c|}{$1+1+1$} & \multicolumn{2}{|c|}{$1+1+1$} & & $1+1+1$ & $1+1+1$ & $1+1+1$ \\
\hline Code & & & & \multicolumn{2}{|c|}{$d_{1}$} & \multicolumn{2}{|c|}{$d_{2}$} & & $d_{3}$ & $d_{4}$ & $d_{5}$ \\
\hline \multicolumn{12}{|c|}{ Clarification: } \\
\hline & \multicolumn{11}{|c|}{ Low capacity of observed combinations of structure, } \\
\hline & \multirow{2}{*}{\multicolumn{11}{|c|}{ Capacity/number of workers which exceed limit values of observed combination of structure, }} \\
\hline & & & \multicolumn{8}{|c|}{ Capacity/number of workers which is within limit values of observed combination of structure. } & \\
\hline
\end{tabular}

In the first place it is necessary to define minimal required capacity $Q_{\text {op-min, }}$ as well as maximal allowed capacity $Q_{\text {op-max }}$ of observed machining operation on the basis of coefficient of capacity reserve $\vartheta$. The quoted coefficients in real process have a task to reduce, as low as possible, stochastical impact of disturbance on production capacity, whereby the value of the coefficient decreases with increasing the sequence number of machining operations in the production line.
The next step is analysis of balance of capacity on the basis of comparison of capacity $Q_{\mathrm{uk}}$ of certain production equipment $M_{i}$ which can be applied for observed machining operation with predefined limitations $Q_{\text {op-min }}$ and $Q_{\text {op-max }}$. For the case of individually examined production equipment that cannot ensure appropriate capacity of production for observed machining operation, mutual combination of available production equipment and comparison of the resulting production capacity with 
the limitations for the observed capacity of machining operation is carried out, Tab. 2.

All combinations that satisfy previous requirement of balance capacities are taken into consideration and subjected to analysis of the working balance by which the coefficient of working necessity $k_{i}$ on analysed potential structures of machining operations is compared with the planned involvement of human labour $k_{\max }$. The coefficient of working necessity $k_{i}$ is given by Eq. (2) and it represents the percentage ratio of demands for human labour during operation of production equipment.

$$
k_{i}=\frac{\sum t_{\mathrm{w}}}{t_{\mathrm{t}}}
$$

where are:

$t_{\mathrm{w}}$ - total amount of working time required by production equipment (e.g.: doing services for production equipment: setting-up, processing, transporting, ...,),

$t_{\mathrm{t}}-$ total time available for work.

The limitation value of the planned engagement of human labour $k_{\max }$ is defined on the basis of experiential values.

If the working balance of observed variation of structure of production equipment is located within the given limits for planned number of workers on observed machining operation, corresponding variation is considered to be adequate and its encoding is performed by using the alphabetical characters for the classification of operations, and numerical characters for the labelling of number of variations (e.g. $a_{3}: a-1^{\text {st }}$ machining operations, variations of the structure of production equipment number 3 ).

In the case that previously described procedure is implemented on every machining operation of observed manufacturing systems the coded values of adequate structures of production equipment on the basis of particular operations are gained, i.e. $a_{1}, a_{2}, \ldots, a_{n} ; b_{1}, b_{2}$, $\ldots, b_{m} ; c_{1}, c_{2}, \ldots, c_{r} ; d_{1}, d_{2}, \ldots, d_{p}, \ldots(n, m, r, p, \ldots \in N)$.

Klein [12] states that classical methods of defining a full plan of experiment has certain lacks which for concrete case are manifested through necessity of realisation of $2^{n}$ experiments, whereby by growing number of influential factors quickly come up to the limit of profitability of experimental tests. In order to resolve this problem, the approach that reduces the number of necessary experiments was applied and it allowed a different number of variations of certain factors. In accordance with the previous statement, for mutual combination of obtained variations of production equipment as the most convenient method algorithm Doptimal design was applied, which allows the subsequent expansion of the factors of observed variables.

By this approach the problem of research of the structure of manufacturing system was solved. Furthermore for parametric optimization Downhillsimplex method was applied, while variation parameters can be represented through:

1) variation of processing time,

2) reducing of services time, and

3) increasing of priority of working place.

\subsection{The problem of the relevant parameters}

The most common practice is that on the basis of partial indicators and subjective opinions, which are obtained on the basis of certain research, it is concluded which aspect of structure and characteristics of manufacturing system will be the most suitable for the analysed manufacturing system. Therefore, it is necessary to find a relevant parameter which allows projection on a dimensionless size of values of investment costs, production costs and the volume of production, but also the costs of unused resources taking into account a realistic projection of the costs that will be manifested during the investment period.

The proposal of authors is the introduction of coefficient of indirect costs $K_{\text {ind-tr }}$ in the analysing process of investment programs which is defined by Eq. (3).

$$
K_{\text {ind-tr }}=\frac{\left(P_{\text {tr } j}-\min \left(P_{\mathrm{tr}}\right)\right) \cdot Q_{\mathrm{pro}}}{\min \left(P_{\mathrm{tr}}\right) \cdot Q_{\mathrm{pr} j}}+1,
$$

where are:

$K_{\text {ind-tr }}-$ coefficient of indirect costs, -

$j$-number of observed structures $(j=1,2, \ldots, m)$, $\min \left(P_{\text {tr }}\right)-$ minimal recorded value of production $\mathrm{KM} / \mathrm{psc}$ (KM - Convertible Mark ( $1 €=1,95 \mathrm{KM})$; psc - pieces), $P_{\mathrm{tr} j}-$ production costs of observed structure $j \mathrm{KM} / \mathrm{psc}$, $Q_{\mathrm{pr} j}$ - achieved annual production of observed structure $j$ pallets/year,

$Q_{\text {pro }}$ - planned annual production pallets/year, $t_{\mathrm{p}}$ - payback period of investment in years.

Experiment with minimal operating costs in the first techno-economic analysis of the potential structures of the manufacturing system and with achieved planned annual production has a theoretical value of $K_{\text {ind-tr }}=1$, while all other experiments with higher production costs or with unfulfilled projected annual production possess $K_{\text {ind-tr }}>1$. With continuing research at some future point and with new structures it is possible to obtain the coefficient of indirect costs $K_{\text {ind-tr }} \leq 1$. Presented percentage difference of coefficients of indirect costs $\Delta_{\text {ind-tr, }}$ Eq. (4), between certain simulation experiments i.e. its coefficient of indirect costs $K_{\text {ind-tri, }}$ and simulation experiment with the minimum value of coefficient of indirect costs $\min \left(K_{\text {ind-tr }}\right)$ indicates the percentage of enlarging or reducing of production costs for a given structure of manufacturing systems.

$$
\Delta_{\text {ind-tr }}=\left[K_{\text {ind-tri }}-\min \left(K_{\text {ind-tr }}\right)\right] \cdot 100 .
$$

Application of Eq. (4) provides a credible comparison of production costs, which will incorporate the comparison, as much as possible, of relevant phenomena (the costs of tools, maintenance, electricity, depreciation, repayment of investments in production equipment, the losses caused by the slowdown, bottlenecks, cancellation, etc.), which was not the case for application of other methods that were used for this problem. 


\section{Plan of experiments}

On the basis of previously described methodology, in this chapter will be presented the results of research of effects of potential variations of structure and parameters of real production line, in order to evaluate the potentials of investment programs.

\subsection{Characteristics of the object of investigation}

Polygon of research is a business system CIMOS TMD Ai Gradačac, Bosnia and Herzegovina, a manufacturer of parts for the automotive industry while the subject of research is manufacturing system consisting of production lines labelled by code name "Ring".

The specified polygon of research is suitable for experimental research of presented issues in Chapter 2 for the following reasons:

- object of research is complex stochastic closed manufacturing system with single type of products in numerous variations-serial production on independent production lines in three shifts and seven working days in a week,

- manufacturing process takes place from year 2003, and therefore it has undergone through various structural modifications, so it is possible to monitor its effects and working features of production equipment,

- $\quad$ there is a constant demand by customers for reducing production costs annually by $5 \%$.

Production lines $(\mathrm{PL})$, hereinafter PL1 $\div$ PL4, during the past six years were exposed to cyclical changes because of changing of boundary conditions of business, and as a result, the existing optimal structure of production lines is shifted into suboptimal area. Respectively, the usage of new technologies (tools, production equipment, etc.) which are aimed to rationalisation of manufacturing process resulted in variation of the structure of manufacturing systems or associated material flows. Table 3 summarizes the diversity of quantitative structure of production equipment that was used during the last six years, for processing on the production lines.

Applied transportation system within the production line is a combination of piece by piece and aggregate transportation by handcart, where transport facilities are:

- Kanban pallets - weight approximately $20 \mathrm{~kg}$ and capacity $60 \mathrm{pcs} /$ pallet - between work positions and buffers,

- object of processing approximately $0,3 \mathrm{~kg}$ - on the workplaces.

Table 3Number of different production equipment within production lines

\begin{tabular}{|c|c|c|}
\hline $\begin{array}{c}\text { Number of } \\
\text { production } \\
\text { equipment units }\end{array}$ & $\begin{array}{c}\text { The amount of different } \\
\text { types of production } \\
\text { equipment }\end{array}$ & $\begin{array}{c}\text { Machining } \\
\text { operations }\end{array}$ \\
\hline 30 & 3 & I \\
\hline 22 & 3 & II \\
\hline 22 & 2 & III \\
\hline 22 & 8 & IV \\
\hline \multicolumn{3}{|c|}{ Total without repeating equipment } \\
\hline 72 & 14 & \\
\hline
\end{tabular}

Given the large number of data obtained in the process of additional analysis of the production lines in this paper considerations are focused on the production line PL1, whereby for other production lines identical conclusions are obtained.

Manufacturing process applied on PL1 is structured from four machining operations with the following production equipment:

The $1^{\text {st }}$ machining operation: Preparation of row materials for further processing, i.e. cutting of steel profiles on predefined thickness with the following production equipment:

- Production equipment A - (Kastossb A2) CNC circular saw with automatic displacement of workpiece after completion of processing,

- Production equipment B - (Index GB100) NC machining lathe with automatic displacement of workpiece after completion of processing and cutting of three workpieces simultaneously,

- Production equipment C - (Daewoo Lynx 200) CNC production lathe for individual cutting of workpieces and manual placing and removing of workpieces from the chuck of machine. Production equipment $\mathrm{C}$ on machining operations I serves for additional machining of unprocessed portion of workpieces from production equipment $\mathrm{B}$.

The $2^{\text {nd }}$ machining operation: Turning of front facing side of a workpiece with the following production equipment:

- Production equipment D - (Mazak QT 6G) CNC production lathe for individual cutting of workpieces and manual placing and removing of workpieces from the chuck of machine,

- Production equipment E - (EmagVL3) CNC production lathe for individual cutting of workpieces, whereby production equipment possesses integrated rotary storage with capacity of 20 workpieces, and automatical placing and removing of workpieces from the chuck of machine.

The $3^{\text {rd }}$ machining operation: Turning of back facing side of a workpiece with the following production equipment:

- Production equipment E - (Emag VL3) CNC production lathe for individual cutting of workpieces, whereby production equipment possesses integrated rotary storage with capacity of 20 workpieces, and automatical placing and removing of workpieces from the chuck of machine,

- Production equipment C - (Daewoo Lynx 200) CNC production lathe for individual cutting of workpieces and manual placing and removing of workpieces from the chuck of machine.

The $4^{\text {th }}$ machining operation: Drilling of the holes on workpieces with the following production equipment:

- Production equipment F - (Daewoo ACE 400) CNC single spindle drilling machine that during one working cycle processes three workpieces,

- $\quad$ Production equipment I - (Mazak Impulse 30H) CNC single spindle drilling machine that during one working cycle processes one workpiece and possesses 
integrated storage with capacity of 60 workpieces. This machine is used for deburring of holes after treatment on production equipment $\mathrm{K}$,

- Production equipment K - (ElhaFM 3+X) CNC multy spindle drilling machine that during one working cycle processes six workpieces and possesses integrated rotary storage with capacity of 60 workpieces,

Production equipment $\mathrm{M}$ - (Doosan V430) CNC single spindle drilling machine that during one working cycle processes three - four workpieces.

\subsection{Preparing for experimental research}

Application of simulation studies for analysis of material flow within manufacturing systems represents the state of technology, VDI 3633, so the same will be used as the basis for the presented research. A simulation model was created on the basis of simulation tools Plant Simulation 8.1 producer: Siemens Tecnomatix, Germany. Developed simulation model is based on discrete event simulation with constant intervals, and it has been developed to take into account the specificities of objects of research, as well as established limits with a certain degree of simplification.

Developed basic simulation models of observed production lines are subjected to validation and verification by using the method of animation, Desk Checking, a test of partial models and methods of comparison with recorded data according to instructions [13] wherein obtained data indicate the credibility of created simulation models, with relative accuracy of models over $92 \%$ [14].

With the aim of studying the impact of structure of manufacturing system and scope of necessary investments on production costs a planned experiment of variations of possible structures of applied production equipment on the PL1 was created. On the basis of the created plan of experiment a comparison of economic effects of possible structure on the object of research was made. In accordance with previous conclusions the methodology of planned experiment based on variations of structure of manufacturing system was applied, section 2.1. For analysis of effects of structure by simulation experiments, one fifth of full design of experiment on the basis of the application of the algorithm D-optimal design was isolated, which resulted in realization of 53 simulation experiments, Tab. 4. The reason for this step can be found in reduction of required time for realisation of experiments, respecting the fact that simulation time of a single experiment is approximately 15 hours. Reducing of number of experiments does not violate the relevance of obtained results because a sufficient number of experiments and equal representation of all possible structures on individual machining operations was provided.

Based on the Life Cycle Costing method [15] for determination of economic indicators during the study of observed structures, as an assumption, all production equipment was treated as new one. Detailed description of object of research, the structure of simulation experiments and their analysis is presented by reference [14].
Table 4 D-optimal design of experiment for PL1

\begin{tabular}{|c|c|c|c|c|}
\hline \multirow{2}{*}{ Exp. } & \multicolumn{4}{|c|}{ The structure of technological systems } \\
\hline & $\mathrm{R}$ & $\mathrm{S}$ & $\mathrm{T}$ & $\mathrm{U}$ \\
\hline 1 & $\mathrm{~B}+\mathrm{C}$ & $3 \cdot \mathrm{D}+\mathrm{E}$ & $2 \cdot \mathrm{C}+\mathrm{E}$ & $4 \cdot \mathrm{F}+4 \cdot \mathrm{M}$ \\
\hline 2 & $5 \cdot \mathrm{A}$ & $2 \cdot \mathrm{D}+\mathrm{E}$ & $3 \cdot \mathrm{C}$ & $4 \cdot \mathrm{F}+4 \cdot \mathrm{M}$ \\
\hline 3 & $\mathrm{~B}+\mathrm{C}$ & $2 \cdot E$ & $3 \cdot \mathrm{C}$ & $7 \cdot \mathrm{M}$ \\
\hline 4 & $\mathrm{~A}+\mathrm{B}$ & $3 \cdot \mathrm{D}+\mathrm{E}$ & $3 \cdot \mathrm{C}$ & $8 \cdot F$ \\
\hline 5 & $\mathrm{~A}+\mathrm{B}$ & $2 \cdot \mathrm{D}+\mathrm{E}$ & $2 \cdot \mathrm{C}+\mathrm{E}$ & $7 \cdot \mathrm{M}$ \\
\hline 6 & $\mathrm{~A}+\mathrm{B}$ & $2 \cdot \mathrm{E}$ & $2 \cdot \mathrm{E}$ & $4 \cdot \mathrm{F}+4 \cdot \mathrm{M}$ \\
\hline 7 & $5 \cdot \mathrm{A}$ & $3 \cdot \mathrm{D}+\mathrm{E}$ & $2 \cdot \mathrm{E}$ & $7 \cdot \mathrm{M}$ \\
\hline 8 & $\mathrm{~B}+\mathrm{C}$ & $2 \cdot \mathrm{D}+\mathrm{E}$ & $2 \cdot E$ & $8 \cdot F$ \\
\hline 9 & $5 \cdot A$ & $2 \cdot E$ & $2 \cdot \mathrm{C}+\mathrm{E}$ & $8 \cdot F$ \\
\hline 10 & $6 \cdot A$ & $4 \cdot D$ & $2 \cdot \mathrm{C}+\mathrm{E}$ & $\mathrm{K}+\mathrm{I}+\mathrm{M}$ \\
\hline 11 & $5 \cdot A$ & $4 \cdot D$ & $2 \cdot C+E$ & $2 \cdot \mathrm{F}+\mathrm{K}+\mathrm{I}$ \\
\hline 12 & $6 \cdot A$ & $2 \cdot \mathrm{D}+\mathrm{E}$ & $2 \cdot C+E$ & $2 \cdot \mathrm{F}+\mathrm{K}+\mathrm{I}$ \\
\hline 13 & $6 \cdot A$ & $4 \cdot D$ & $2 \cdot C+E$ & $4 \cdot \mathrm{F}+4 \cdot \mathrm{M}$ \\
\hline 14 & $5 \cdot A$ & $3 \cdot \mathrm{D}+\mathrm{E}$ & $2 \cdot \mathrm{C}+\mathrm{E}$ & $\mathrm{K}+\mathrm{I}+\mathrm{M}$ \\
\hline 15 & $6 \cdot A$ & $3 \cdot \mathrm{D}+\mathrm{E}$ & $2 \cdot E$ & $2 \cdot \mathrm{F}+\mathrm{K}+\mathrm{I}$ \\
\hline 16 & $\mathrm{~B}+\mathrm{C}$ & $4 \cdot D$ & $2 \cdot E$ & $\mathrm{~K}+\mathrm{I}+\mathrm{M}$ \\
\hline 17 & $6 \cdot A$ & $2 \cdot E$ & $3 \cdot \mathrm{C}$ & $\mathrm{K}+\mathrm{I}+\mathrm{M}$ \\
\hline 18 & $A+B$ & $4 \cdot D$ & $3 \cdot \mathrm{C}$ & $2 \cdot \mathrm{F}+\mathrm{K}+\mathrm{I}$ \\
\hline 19 & $6 \cdot A$ & $4 \cdot D$ & $3 \cdot \mathrm{C}$ & $7 \cdot \mathrm{M}$ \\
\hline 20 & $\mathrm{~B}+\mathrm{C}$ & $2 \cdot E$ & $2 \cdot \mathrm{C}+\mathrm{E}$ & $2 \cdot \mathrm{F}+\mathrm{K}+\mathrm{I}$ \\
\hline 21 & $A+B$ & $2 \cdot \mathrm{D}+\mathrm{E}$ & $2 \cdot E$ & $\mathrm{~K}+\mathrm{I}+\mathrm{M}$ \\
\hline 22 & $6 \cdot A$ & $2 \cdot E$ & $2 \cdot E$ & $8 \cdot F$ \\
\hline 23 & $A+B$ & $4 \cdot D$ & $2 \cdot \mathrm{C}+\mathrm{E}$ & $8 \cdot F$ \\
\hline 24 & $\mathrm{~B}+\mathrm{C}$ & $2 \cdot \mathrm{D}+\mathrm{E}$ & $3 \cdot \mathrm{C}$ & $8 \cdot F$ \\
\hline 25 & $5 \cdot A$ & $4 \cdot D$ & $2 \cdot E$ & $4 \cdot \mathrm{F}+4 \cdot \mathrm{M}$ \\
\hline 26 & $5 \cdot A$ & $2 \cdot E$ & $3 \cdot \mathrm{C}$ & $2 \cdot \mathrm{F}+\mathrm{K}+\mathrm{I}$ \\
\hline 27 & $6 \cdot A$ & $3 \cdot \mathrm{D}+\mathrm{E}$ & $3 \cdot \mathrm{C}$ & $4 \cdot \mathrm{F}+4 \cdot \mathrm{M}$ \\
\hline 28 & $\mathrm{~A}+\mathrm{B}$ & $2 \cdot E$ & $2 \cdot \mathrm{C}+\mathrm{E}$ & $7 \cdot \mathrm{M}$ \\
\hline 29 & $6 \cdot A$ & $2 \cdot \mathrm{D}+\mathrm{E}$ & $2 \cdot E$ & $7 \cdot \mathrm{M}$ \\
\hline 30 & $5 \cdot A$ & $2 \cdot \mathrm{D}+\mathrm{E}$ & $3 \cdot \mathrm{C}$ & $\mathrm{K}+\mathrm{I}+\mathrm{M}$ \\
\hline 31 & $A+B$ & $3 \cdot \mathrm{D}+\mathrm{E}$ & $2 \cdot E$ & $2 \cdot \mathrm{F}+\mathrm{K}+\mathrm{I}$ \\
\hline 32 & $\mathrm{~B}+\mathrm{C}$ & $4 \cdot D$ & $3 \cdot \mathrm{C}$ & $7 \cdot \mathrm{M}$ \\
\hline 33 & $\mathrm{~B}+\mathrm{C}$ & $3 \cdot \mathrm{D}+\mathrm{E}$ & $2 \cdot \mathrm{C}+\mathrm{E}$ & $\mathrm{K}+\mathrm{I}+\mathrm{M}$ \\
\hline 34 & $5 \cdot A$ & $4 \cdot D$ & $2 \cdot E$ & $8 \cdot F$ \\
\hline 35 & $\mathrm{~B}+\mathrm{C}$ & $2 \cdot E$ & $2 \cdot E$ & $4 \cdot \mathrm{F}+4 \cdot \mathrm{M}$ \\
\hline 36 & $A+B$ & $2 \cdot E$ & $3 \cdot \mathrm{C}$ & $\mathrm{K}+\mathrm{I}+\mathrm{M}$ \\
\hline 37 & $\mathrm{~A}+\mathrm{B}$ & $2 \cdot \mathrm{D}+\mathrm{E}$ & $2 \cdot \mathrm{C}+\mathrm{E}$ & $4 \cdot \mathrm{F}+4 \cdot \mathrm{M}$ \\
\hline 38 & $6 \cdot A$ & $3 \cdot \mathrm{D}+\mathrm{E}$ & $3 \cdot \mathrm{C}$ & $8 \cdot F$ \\
\hline 39 & $5 \cdot A$ & $3 \cdot \mathrm{D}+\mathrm{E}$ & $2 \cdot \mathrm{C}+\mathrm{E}$ & $7 \cdot \mathrm{M}$ \\
\hline 40 & $\mathrm{~B}+\mathrm{C}$ & $2 \cdot \mathrm{D}+\mathrm{E}$ & $3 \cdot \mathrm{C}$ & $2 \cdot \mathrm{F}+\mathrm{K}+\mathrm{I}$ \\
\hline 41 & $6 \cdot A$ & $2 \cdot E$ & $2 \cdot \mathrm{C}+\mathrm{E}$ & $8 \cdot F$ \\
\hline 42 & $A+B$ & $3 \cdot \mathrm{D}+\mathrm{E}$ & $3 \cdot \mathrm{C}$ & $4 \cdot \mathrm{F}+4 \cdot \mathrm{M}$ \\
\hline 43 & $\mathrm{~B}+\mathrm{C}$ & $3 \cdot \mathrm{D}+\mathrm{E}$ & $2 \cdot E$ & $7 \cdot \mathrm{M}$ \\
\hline 44 & $5 \cdot A$ & $2 \cdot E$ & $2 \cdot E$ & $\mathrm{~K}+\mathrm{I}+\mathrm{M}$ \\
\hline 45 & $6 \cdot A$ & $2 \cdot \mathrm{D}+\mathrm{E}$ & $2 \cdot E$ & $2 \cdot \mathrm{F}+\mathrm{K}+\mathrm{I}$ \\
\hline 46 & $\mathrm{~A}+\mathrm{B}$ & $4 \cdot \mathrm{D}$ & $2 \cdot E$ & $2 \cdot \mathrm{F}+\mathrm{K}+\mathrm{I}$ \\
\hline 47 & $5 \cdot A$ & $2 \cdot \mathrm{D}+\mathrm{E}$ & $3 \cdot \mathrm{C}$ & $7 \cdot \mathrm{M}$ \\
\hline 48 & $\mathrm{~B}+\mathrm{C}$ & $4 \cdot \mathrm{D}$ & $3 \cdot \mathrm{C}$ & $8 \cdot F$ \\
\hline 49 & $\mathrm{~B}+\mathrm{C}$ & $2 \cdot \mathrm{D}+\mathrm{E}$ & $2 \cdot C+E$ & $\mathrm{~K}+\mathrm{I}+\mathrm{M}$ \\
\hline 50 & $6 \cdot A$ & $4 \cdot \mathrm{D}$ & $3 \cdot \mathrm{C}$ & $\mathrm{K}+\mathrm{I}+\mathrm{M}$ \\
\hline 51 & $\mathrm{~B}+\mathrm{C}$ & $2 \cdot E$ & $2 \cdot E$ & $2 \cdot \mathrm{F}+\mathrm{K}+\mathrm{I}$ \\
\hline 52 & $\mathrm{~B}+\mathrm{C}$ & $2 \cdot E$ & $2 \cdot E$ & $2 \cdot \mathrm{F}+\mathrm{K}+\mathrm{I}$ \\
\hline 53 & $\mathrm{~B}+\mathrm{C}$ & $2 \cdot E$ & $2 \cdot E$ & $2 \cdot \mathrm{F}+\mathrm{K}+\mathrm{I}$ \\
\hline
\end{tabular}

Clarification: $\mathrm{R}-\mathrm{I}$ machining operation, $\mathrm{S}-\mathrm{II}$ machining operation, $\mathrm{T}$

- III machining operation, U - IV machining operation.

\section{Experimental results}

In accordance with the presented theoretical assumptions, the developed simulation model of the analysed manufacturing systems and in accordance with the adopted plan of experiment the set of planned simulation experiments was carried out. As outcomes of above mentioned, results of simulation experiment 
labelled by code 51 are presented in Fig. 1 which in essence presents real structure of PL1. At the above mentioned figure, abscissa represents simulation time while the ordinate represents difference between actual capacity of individual machining operations (II-I, III-II, IV-III, IV-II, III-I, IV-I) expressed in pallets.

Given to that, the capacity of buffers - storages between certain operations within production line (Fig. 1: II-I, III-II, IV-III) is 60 Kanban pallets, and in some working positions in a particular machining operation in warehouses it is possible to secondarily store up to 10 Kanban pallets among the phases, so that emptying of certain individual buffer will be performed when the capacity difference between the adjacent machining operations reaches a value of at least 50 Kanban pallets (phenomenon of wide places). The negative value of the difference between the capacities of the neighbouring operations refers to backfill buffers (phenomenon of bottleneck), Fig. 1.
Analysis of the obtained values indicates the influence of level of balancing production and the situation in the failure of achieved volume of production, i.e. of a value of cumulative production costs, Tab. 5 . The difference in realized annual production is the result of degree of balancing of production lines and reserve of capacity, Tab. 2. Reason for that are the facts that the biggest impact on this dispersion has the occurrence of situations of failure of production equipment and occurrence of bottlenecks within production lines. Therefore in Fig. 2 is presented timeline of production costs for the experiments with a minimum level of achieved production of $99,5 \%$. This is primarily done with the aim to compare effects of structure of PL1 without additional transformation of values, i.e. the value of the necessary investment and function of production costs.

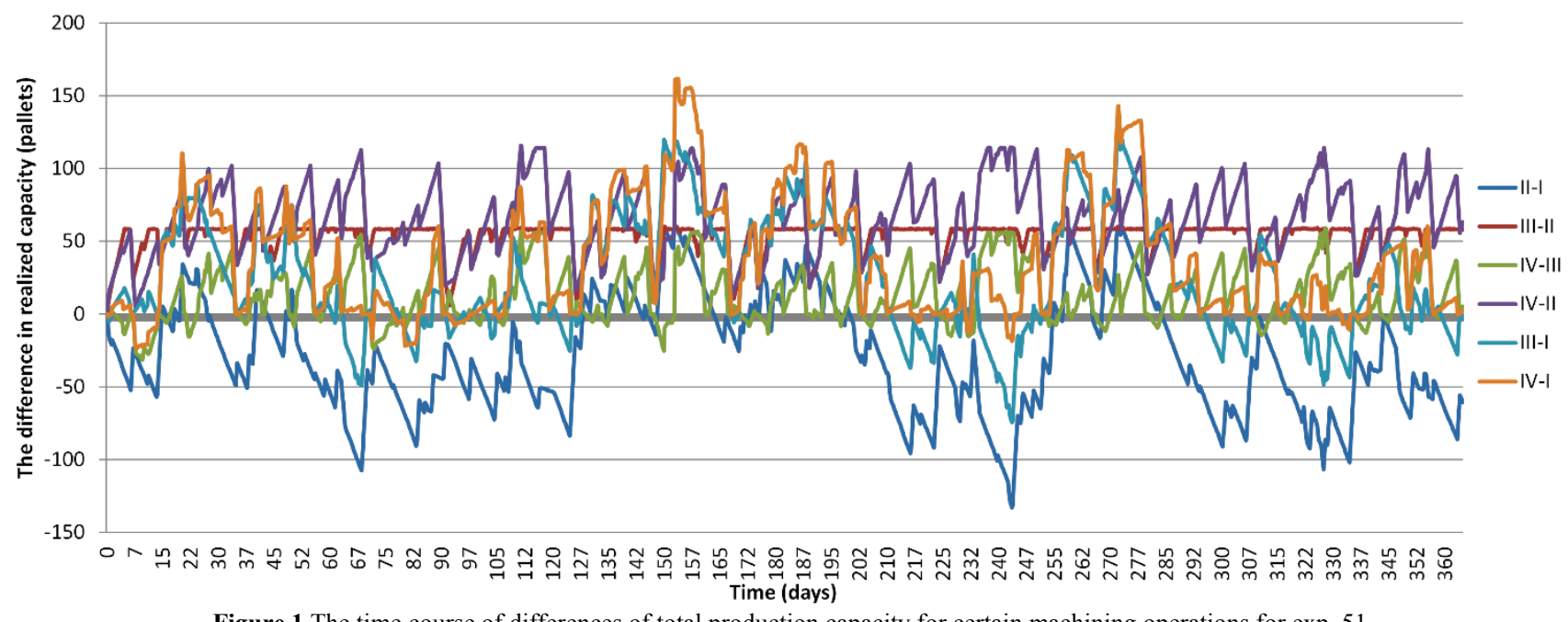

Figure 1 The time course of differences of total production capacity for certain machining operations for exp. 51
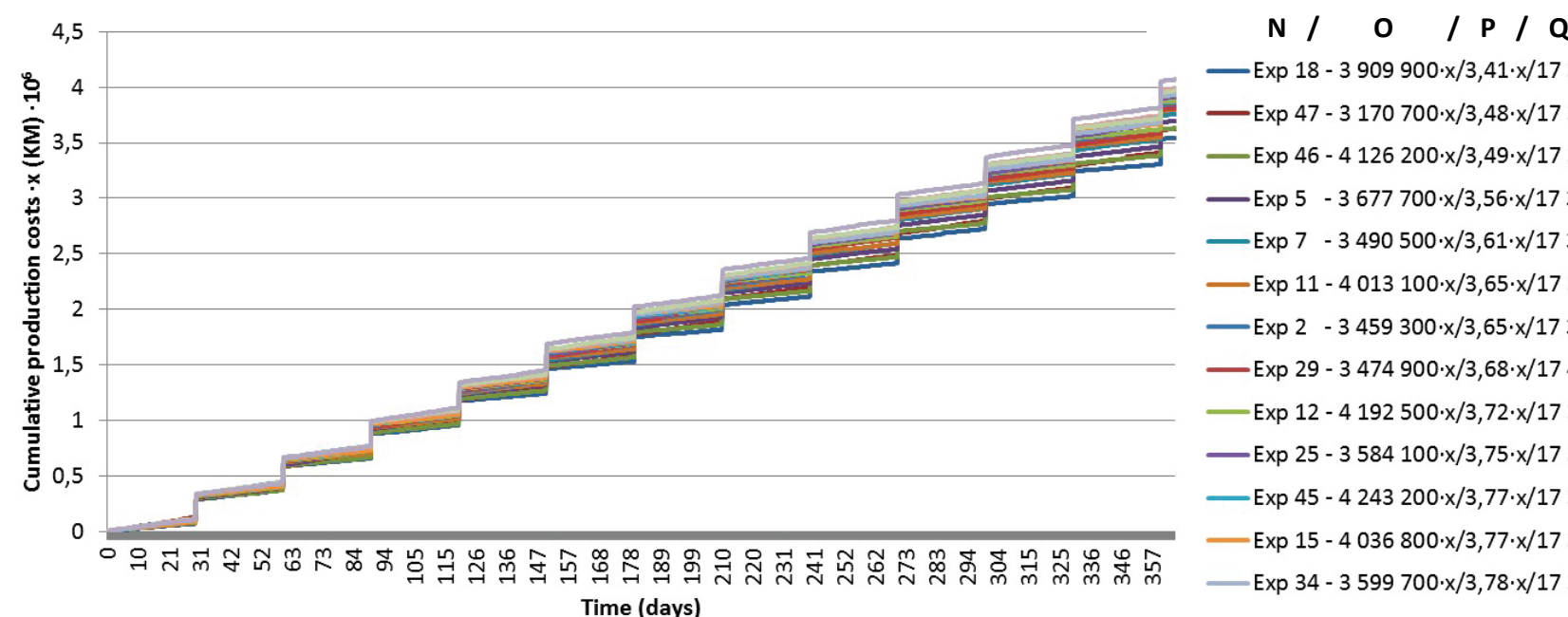

- Exp 18 - $3909900 \cdot x / 3,41 \cdot x / 17327$

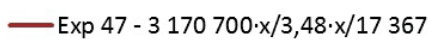

- Exp $46-4126200 \cdot x / 3,49 \cdot x / 17328$

- Exp $5-3677700 \cdot x / 3,56 \cdot x / 17323$

$-\operatorname{Exp} 7-3490500 \cdot x / 3,61 \cdot x / 17373$

- Exp $11-4013$ 100·x/3,65·x/17 373

-Exp $2-3459300 \cdot x / 3,65 \cdot x / 17378$

-Exp 29 - $3474900 \cdot x / 3,68 \cdot x / 17402$

$-\operatorname{Exp} 12-4192500 \cdot x / 3,72 \cdot x / 17377$

-Exp 25 - $3584100 \cdot x / 3,75 \cdot x / 17372$

—Exp $45-4243200 \cdot x / 3,77 \cdot x / 17368$

- Exp $15-4036800 \cdot x / 3,77 \cdot x / 17379$

Time (days)

Exp 34 - $3599700 \cdot x / 3,78 \cdot x / 17376$

Clarification: $N$ - Experiment; $O$ - Required Amount of Investment $\times x(\mathrm{KM}) ; P$ - Production Costs per Units $\times x(\mathrm{KM} / \mathrm{pcs}) ; Q-\mathrm{Quantity}$ of ANNUAL Production (pallet/annual).

Figure 2 Time functions of production costs for PL1

Table 5 The range of values obtained for the simulation experiment

\begin{tabular}{|l|c|}
\hline Relevant parameters & PL1 \\
\hline Investments $\times x, \mathrm{KM}$, & $3155100 \div 4360200$ \\
\hline unit costs of production $\times x, \mathrm{KM} / \mathrm{pcs}$ & $3,4087 \div 4,2208$ \\
\hline Achieved annual production, pallets/year & $15873 \div 17402$ \\
\hline
\end{tabular}

In order to maintain the confidentiality of business (financial) results of the polygon of research the coefficient $x$ was introduced, which figures in presentation of all economic data. The ideal situation for which one of the previous solutions should correspond is that a minimum investment in existing structure of 
manufacturing system results in a minimal costs and higher volume of annual production. This statement fully corresponds to the general belief that increasing the amount of investment significantly reduces production costs. However, from previous diagram, Fig. 2, it can be clearly seen that the amount of required investment and the size of cumulative costs, and thus the size of the costs per unit of production, are not in a proportional relationship.

Based on previously exposed it can be concluded that between production costs and the amount of necessary investments does not exist proportional dependence for certain structures of PL1. The reasons for this conclusion can be found in a variety of influential factors (processing time, time and period of changing of tools, state of the failure, the degree of balancing, different technologies and tools, etc.) which are in constant interaction so they negatively affect the characteristics of the production line.

In addition to the previous factors, which are technical in nature, production costs are influenced by certain economic factors too. Those factors are reflected in the overvaluation of production equipment on the one hand, because the ratio between price and performance does not have a linear characteristic, while on the other hand the price and intensity of wear of tools have an impact on different technologies that are used for work on the same machining operations.

Based on the previous conclusion there is a need for adjustment of production equipment to the customer requirements in the future and not for adjustment of a customer to the characteristics of production equipment. Additionally it is necessary to generate a database that will contain all relevant information for the creation of a simulation element for observed type of production equipment in order to converge to the structure of manufacturing systems with satisfactory characteristics prior to purchases.

By analysis of the coefficients of indirect costs $K_{\text {ind-tr }}$ for observed potential structures of PL1, Fig. 3, for further process of parametric optimization five best ranked structures of PL1 based on the value of the percentage difference between the coefficients of indirect costs $\Delta_{\text {ind-tr }}$ are elected.

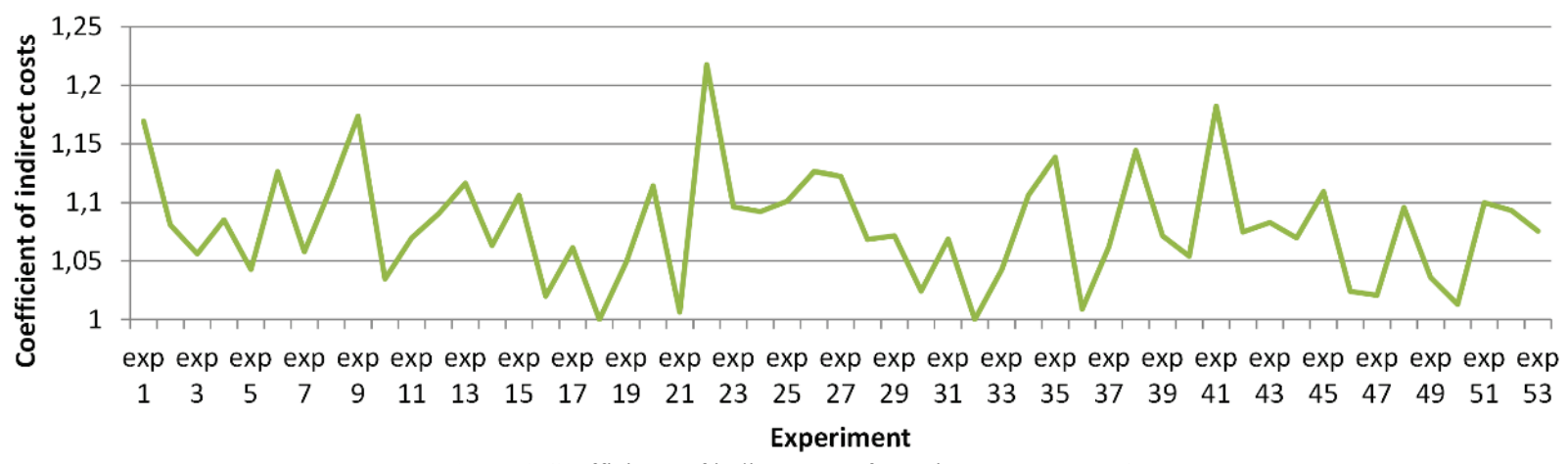

Figure 3 Coefficients of indirect costs for a given structure PL1

Table 6 Characteristics of best ranked structures PL1

\begin{tabular}{|c|c|c|c|c|c|c|c|c|}
\hline \multirow{2}{*}{ Experiment } & \multicolumn{4}{|c|}{ Structure of technological operations } & \multicolumn{4}{|c|}{ Techno-economic indicators } \\
\hline & $\mathrm{R}$ & $\mathrm{S}$ & $\mathrm{T}$ & $\mathrm{U}$ & $\mathrm{O}$ & $\mathrm{P}$ & $\mathrm{Q}$ & $\mathrm{V}$ \\
\hline 54 & $\mathrm{~A}+\mathrm{B}$ & $4 \cdot \mathrm{D}$ & $3 \cdot \mathrm{C}$ & $\mathrm{K}+\mathrm{I}+\mathrm{M}$ & 3623100 & 3,2386 & 16816 & $-5,1640686$ \\
\hline 18 & $\mathrm{~A}+\mathrm{B}$ & $4 \cdot \mathrm{D}$ & $3 \cdot \mathrm{C}$ & $2 \cdot \mathrm{F}+\mathrm{K}+\mathrm{I}$ & 3903900 & 3,4087 & 17327 & 0,0000000 \\
\hline 32 & $\mathrm{~B}+\mathrm{C}$ & $4 \cdot \mathrm{D}$ & $3 \cdot \mathrm{C}$ & $7 \cdot \mathrm{M}$ & 3174600 & 3,4090 & 16322 & 0,0093834 \\
\hline 21 & $\mathrm{~A}+\mathrm{B}$ & $2 \cdot \mathrm{D}+\mathrm{E}$ & $2 \cdot \mathrm{E}$ & $\mathrm{K}+\mathrm{I}+\mathrm{M}$ & 3942900 & 3,4310 & 16706 & 0,6814638 \\
\hline 36 & $\mathrm{~A}+\mathrm{B}$ & $2 \cdot E$ & $3 \cdot \mathrm{C}$ & $\mathrm{K}+\mathrm{I}+\mathrm{M}$ & 3818100 & 3,4408 & 16370 & 1,0010753 \\
\hline 50 & $6 \mathrm{~A}$ & $4 \cdot \mathrm{D}$ & $3 \cdot \mathrm{C}$ & $\mathrm{K}+\mathrm{I}+\mathrm{M}$ & 3642600 & 3,4546 & 16858 & 1,3900071 \\
\hline $\begin{array}{l}\text { Clarification } \\
\mathrm{R}-\text { I machin } \\
\mathrm{T}-\text { III mach } \\
\mathrm{O}-\text { Investm } \\
\mathrm{Q}-\text { Achieve }\end{array}$ & $\begin{array}{l}\text { operat } \\
\text { g oper } \\
\times x, \mathrm{~K} \\
\text { inual p }\end{array}$ & tion, pa & 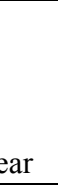 & $\begin{array}{l}\mathrm{S}-\mathrm{II} \mathrm{m} \\
\mathrm{U}-\mathrm{IV} \\
\mathrm{P}-\text { proc } \\
\mathrm{V}-\text { the } \\
\Delta_{\text {ind-tr }}\end{array}$ & $\begin{array}{l}\text { ing operatio } \\
\text { ning operati } \\
\text { n costs per } \\
\text { htage differ }\end{array}$ & $\begin{array}{l}x, \mathrm{KM} / \mathrm{p} \\
\text { etween } \mathrm{t}\end{array}$ & fficients & lirect costs \\
\hline
\end{tabular}

Additional analysis of simulation experiments has indicated that certain structures of machining operations have a significant incidence in the highest-seeded structures. Based on those facts simulation experiment 54 has been created. That experiment takes the top spot in the rankings on the basis of percentage difference of the coefficients of indirect costs $\Delta_{\text {ind-tr, Eq. (4), Tab. } 6 .}$

For previously defined structure of manufacturing system (experiment 54 for PL1) minimum of costs per unit of production was determined, so it is proven that this approach on the basis of algorithm of D-optimal design can determine the structure of manufacturing systems that possess minimum of production costs. On the basis of this it can be concluded that an individual structure on certain machining operations indicates the optimal structure of production line, but in addition it is necessary to be cautious because of degree of balancing on individual machining operations.

For further process of optimization parameters of chosen structure of production lines were used, Tab. 6, while as parameters for parametric optimization were used, Tab. 7:

1) reducing of services time- direct impact on improving of level of balancing of manufacturing systems 
(quality control, tool changes, changes of work piece and the elimination of failure),

2) increasing of priority of working place - definition of priority of manufacturing on production equipment with lower production costs.
In Tab. 7 the results of micro optimization process are presented, and it is evident that some potential structure of PL1 changed their positions in regard to previous ranking.

Table 7 Summary results of the micro optimization process of best ranked structures on PL1

\begin{tabular}{|c|c|c|c|c|c|}
\hline \multirow{2}{*}{ Experiment } & \multirow{2}{*}{ Optimisation parameters } & \multicolumn{4}{|c|}{ Techno - economic indicators } \\
\hline & & $\mathrm{O}$ & $\mathrm{P}$ & $\mathrm{Q}$ & $\mathrm{V}$ \\
\hline $\exp 54$ & $\begin{array}{l}\text { Percentage share of time of servicing of production equipment } \\
\text { - type K } 90 \% \text {, M } 90 \%\end{array}$ & 3623100 & 3,1977 & 17104 & $-6,2978912$ \\
\hline $\exp 32$ & $\begin{array}{l}\text { Percentage share of time of servicing of production equipment } \\
\text { - type B } 90 \%\end{array}$ & 3174600 & 3,2590 & 16978 & $-4,5013798$ \\
\hline $\exp 21$ & $\begin{array}{l}\text { Percentage share of time of servicing of production equipment } \\
\text { - type B } 90 \%, \mathrm{~K} 90 \%\end{array}$ & 3942900 & 3,3312 & 17171 & $-2,3041805$ \\
\hline $\exp 18$ & $\begin{array}{l}\text { Percentage share of time of servicing of production equipment } \\
\text { - type B } 95 \% \text { and reducing of working time of production } \\
\text { equipment - type F for } 5 \text { working shifts by week }\end{array}$ & 3903900 & 3,3387 & 17379 & $-2,0562866$ \\
\hline $\exp 50$ & $\begin{array}{l}\text { Percentage share of time of servicing of production equipment - } \\
\text { type K } 90 \%, \mathrm{M} 90 \%\end{array}$ & 3642600 & 3,3863 & 17195 & $-0,6650529$ \\
\hline $\exp 36$ & $\begin{array}{l}\text { Percentage share of time of servicing of production equipment } \\
\text { - type B } 90 \% \text {, E } 90 \%\end{array}$ & 3818100 & 3,3925 & 16562 & $-0,4993587$ \\
\hline \multicolumn{6}{|c|}{$\begin{array}{ll}\text { Clarification: } & \mathrm{P}-\text { production costs per unit } \times x, \mathrm{KM} / \mathrm{pcs} \\
\mathrm{O}-\text { Investments } \times x, \mathrm{KM} & \mathrm{V}-\text { the percentage difference between the coefficients of indirect costs } \\
\mathrm{Q}-\text { Achieved annual production, pallets/year } & \Delta_{\text {ind-tr }}\end{array}$} \\
\hline
\end{tabular}

The primary reason for this occurrence is reducing of impact of imbalances of certain machining operations within the production line which has resulted in an increasing of production volume, i.e. reduction of production costs and value of percentage difference of coefficients of indirect costs $\Delta_{\text {ind-tr }}$. Based on the aforementioned, it can be concluded that a considerable potential for reduction of production costs exists in this process.

Analysis of structure of individual production lines based on the maximum achieved production capacity, simulation experiment 18 , has not been met with the minimum cost of production and thus the minimal coefficient of indirect costs $\min \left(K_{\text {ind-tr }}\right)$. Identical procedure took place also with the structure with the minimal and maximal size of the investment, i.e. simulation experiments 32 and 21, which also did not possess the minimal coefficient of indirect costs $\min \left(K_{\text {ind- }}\right.$ tr). The structure determined by simulation experiment 54 has by $14,84 \%$ higher investment costs in comparison with the cheapest structure (Tab. 4), and also has 17,12\% less performance than the maximum achieved production, has a minimum value of production costs and the coefficient of indirect costs $K_{\text {ind-tr, }}$, that is, the percentage difference of coefficients of indirect costs $\Delta_{\text {ind-tr }}$.

This phenomenon can be justified only by the fact that in addition to the amount of necessary investments, other factors have a significant impact on production costs. Some of them are: material flow, characteristics of manufacturing equipment (services time, durability, number of spindles, capacity, etc.) and the degree of balance between the individual machining operations in the manufacturing process

\section{Conclusion}

During the assessment making process of investment programs on the basis of reorganization, revitalisation or designing of a new manufacturing system, it is necessary to carry out a comparative analysis of expenditures during the reference period of lifetime of the system, i.e. along with an initial amount of necessary investment costs of labour, maintenance and energy, taken into consideration must also be the "price of money" on the market, inflation, etc.

Previously presented study has proven that the ratio between the amount of required investment and production cost is not in proportional dependencies. The consequence of the above presented proof is a necessity to have relevant information and indicators on the basis of which will be determined techno-economic effects which bring the individual investment program during designing of a structure of manufacturing systems with the lowest production costs. In order to realize the defined conclusion in everyday industrial practice, respecting the fact that the production equipment needs to match the user's requirements and not vice versa, it is necessary to ensure the creation of adequate databases with relevant information about elements of simulation (technoeconomic indicators of production equipment) in order to perform a comprehensive analysis of structure with the aim to converge towards the manufacturing system with satisfactory performance before its procurement.

The presented methodology and application of the coefficient of indirect costs $K_{\text {ind-tr, }}$ i.e. percentage difference of coefficients of indirect costs $\Delta_{\text {ind-tr, }}$ which is based on the size of costs of unused resources, provides relevant indicators for the analysis of manufacturing system in order to evaluate investment programs, so that minimum value of coefficient of indirect costs $K_{\text {ind-tr }}$ within analysed structure of manufacturing system indicates the structure with minimal production costs, which is appropriate for application in a case of production equipment with different levels of depreciation too. 
The choice of structure of manufacturing systems is a macro optimization, while the micro optimizations can be made on the basis of variations of processing time, the variation of services time and increasing the priority of workplace. Through variation of services time and by increasing priority of workplace it is possible to reduce overall production costs by $2 \%$ approximately and in the case of series production this represents a substantial saving.

Based on the previously presented theoretical and experimental research it can be concluded that the methodology presented in this paper is a new, innovative and systematic approach for determination of structure of manufacturing systems which takes into account all the stochastic events within the process of production, all with the aim of obtaining most credible model of behaviour of manufacturing system and determination of associated production costs, which was not the case with the methods applied so far. Additionally the methodology provides the choice of the optimal structure of manufacturing system in the function of total production costs (direct and indirect) and value of investments needed for establishment of the required production process.

\section{References}

[1] Sesterhenn, M. Bewertungssystematik zur Gestaltung struktur- und betriebsvariabler Produktionssysteme. // PhD thesis, RWTH Aachen University, 2003.

[2] Koren, Y.; Hu, J.; Weber T. Impact of Manufacturing System Configuration on Performance. // Annals of the CIRP. 47, 1(1998), pp. 369-378. DOI: 10.1016/S00078506(07)62853-4

[3] Cochran, D. S.; Linck, J.; Mauderer, M.; Reinhart, G. Decision Support for Manufacturing System Design Combining a Decomposition Methodology with Procedural Manufacturing System Design. // The Third World Congress on Intelligent Manufacturing Processes and Systems /Cambridge, 2000, pp. 9-16.

[4] Westkämper, E. Wandlungsfähige Unternehmensstrukturen für variantenreiche Serienproduktion, Springer Verlag, Berlin, 2003.

[5] Koren, Y.; Shpitalni, M. Design of reconfigurable manufacturing systems. // Journal of Manufacturing Systems. 29, 4(2010) pp. 130-141. DOI: 10.1016/j.jmsy.2011.01.001

[6] Zhu, X. W. Calculating the number of possible system configuration. // Tech. report ERC/RMS, 2005.

[7] Azab, A.; El Maraghy, H. Mathematical Modeling for Reconfigurable Process Planning. // CIRP Annals. 56, 1(2007), pp. 467-472. DOI: 10.1016/j.cirp.2007.05.112

[8] Cerjaković, E.; Tufekčić, Dž.; Topčić, A.; Šelo, R.; Ćelović, Š. Stabilisation of production lines by using of simulation study methodology. // International Virtual Journal - MTM. 4, 1-2(2010), pp. 24-27.

[9] Topčić, A.; Šelo, R.; Cerjaković, E. Optimisation of reloading segments of internal transportation systems. // Journal Technics, Technologies, Education, Management TTEM. 5, 2(2010), pp. 259-270.

[10] Arunkumar, Y.; Patil, R.; Mohankumar, S. Discrete Event Simulation for Increasing Productivity in Digital Manufacturing. // International Journal of Engineering Research and Development. 1, 10(2012), pp. 36-40.

[11] Cisek, R. Planung und Bewertung von Rekonfigurationsprozessen in Produktionssystemen. // PhD thesis, Technical University of Munich, Herbert Utz Verlag GmbH, 2005.
[12] Klein, B. Versuchsplanung - DoE: Einführung in die Taguchi/Shainin-Methodik, Oldenbourg Wissenschaftsverlag, Munchen, 2007.

[13] Rabe, M.; Spieckermann, S.; Wenzel, S. Verifikation und Validierung für die Simulation in Produktion und Logistik Vorgehensmodelle und Techniken, Springer-Verlag, Berlin, 2008.

[14] Cerjaković, E. Utjecaj strukture proizvodno-tehnološkog sistema i obima investicije na troškove proizvodnje. // $\mathrm{PhD}$ thesis, University of Tuzla, 2012.

[15] Lauven, L.; Wiedenmann, S.; Geldermann, J. Lebenszykluskosten als Entscheidungshilfe beim Erwerb von Werkzeugmaschinen, Research Paper Nr. 10, GeorgAugust- University Göttingen, 2010.

\section{Authors' addresses}

Edin Cerjaković, Assistant Professor

University of Tuzla

Faculty of Mechanical Engineering Tuzla

Univerzitetska 4, 75000 Tuzla, Bosnia and Herzegovina

E-mail: edin.cerjakovic@untz.ba

Alan Topčić, Associate Professor

University of Tuzla

Faculty of Mechanical Engineering Tuzla

Univerzitetska 4, 75000 Tuzla, Bosnia and Herzegovina

E-mail: alan.topcic@untz.ba

\section{Džemo Tufekčić, Full Professor}

University of Tuzla

Faculty of Mechanical Engineering Tuzla

Univerzitetska 4, 75000 Tuzla, Bosnia and Herzegovina

e-mail: dzemo_tufekcic@hotmail.com

Ivica Veža, Full Professor

University of Split

Faculty of Electrical Engineering,

Mechanical Engineering and Naval Architecture

R. Boskovica 32, 21000 Split, Croatia

E-mail: iveza@fesb.hr 